\author{
Asian Journal of Economic Modelling \\ $\operatorname{ISSN}(e): \quad 2312-3656$ \\ $\operatorname{ISSN}(p): \quad 2313-2884$ \\ DOI: $10.18488 /$ journal.8.2014.21.18.31 \\ Vol. 2, No. 1, 18-31 \\ (C) 2014 AESS Publications. All Rights Reserved. \\ URL: www.aessweb.com
}

\title{
OPERATIONS OF STREET FOOD VENDORS AND THEIR IMPACT ON SUSTAINABLE URBAN LIFE IN HIGH DENSITY SUBURBS OF HARARE, IN ZIMBABWE
}

Tavonga Njaya

\author{
Faculty of Commerce and Law Zimbabwe Open University, Zimbabwe \\ (+ Corresponding author)
}

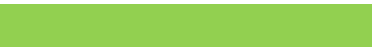

\section{Keywords}

Harare

Food vendor

Formalization

Suburb

Informal economy

Street food

Stall.

\section{ABSTRACT}

The study sought to investigate the nature and operations of street food vendors including socio-economic features influencing street food vending spatial distribution and its impact on the local environment and urban life within the context of sustainable development. Data were collected through field notes, in-depth personal interviews, direct observations and documentary reviews so as to triangulate the evidence. Sixty semi-structured questionnaires were administered to collect socioeconomic and technical data pertaining to street food vending. The study showed that street food vending, far from being a hindrance to progress and sustainable development, is in fact the basis of an alternative street economy which is people friendly and with the necessary institutional and infrastructural support could be both environmental-sensitive and energy conscious. Although street food vending is illegal, it significantly helped to reduce unemployment, increased incomes of vendors and provided urban dwellers with inexpensive and varied indigenous meals. The government should recognise street food industry through legislation and introduction of a code of practice for street food vendors. This would require city council to construct decent shelters and provide essential public utilities such as potable water, electricity and public toilets. What is needed to advance the position of street food vendors is to strengthen their capacities and skills through training, credit, information and infrastructure so as to enhance their competitiveness and productivity. There is need for further research to describe the nature of street vending and quantify the consumption of street foods in Zimbabwe and their economic benefits as well as ways to improve the standards of street food. 


\section{INTRODUCTION}

Economic downturn, rapid urban population growth, upsurge in HIV and AIDS epidemic, political instability, rising unemployment and lower take-home pay drove some Harare residents into the informal sector as food vendors. The rapid urbanisation in the past decades has led urban services to be stretched beyond their limits, resulting in inadequate supplies of potable water, sewage disposal and other necessary services. Food legislation, regulation and enforcement have constantly failed to reflect the changing circumstances and incorporate them into town planning to ensure sustainability of street food vending and hence its contribution to sustainable development.

The informal sector covers two groups of labour market activities. It is formed by the coping behaviour of individuals during economic downturn and rising unemployment. The informal sector can also be a product of rational behaviour of innovative entrepreneurs that seek to escape government regulations and registration of business enterprises.

The role of the informal sector is complex and controversial. The informal sector provides jobs, bolsters entrepreneurial activity and helps alleviate poverty. In Zimbabwe, the informal sector has become the largest employer due to economic downturn. Workers in the informal sector earn less income, have unstable income, and do not have access to basic protections and services (Beneria and Floro, 2006). In the majority of cases, there is no compliance to government regulations on the business activities. As a result, producers in the informal sector produce with less assistance from public services than is available to producers in the formal sector. These public services include the protection of property rights by the police and the courts as well as public utilities, such as roads, electricity, potable water and waste disposal which hamper their productivity. Producers in the informal sector sometimes rely on cheap family labour.

Although statistics on the informal economy are unreliable by virtue of the subject, they can provide a tentative picture of the sector's contribution to the economy. The lack of data on the informal sector makes it difficult to make comparisons within and between countries. Informal employment makes up 48 percent of non-agricultural employment in North Africa, 51 percent in Latin America, 65 percent in Asia and 72 percent in Sub-Saharan Africa (ILO (International Labour Organisation), 2002). If agricultural employment is included, the percentage rises beyond 90 percent in many sub-Saharan African countries. Women dominate the informal sector in most Sub-Saharan African countries, where they are found in the fields of trading, agriculture and food processing (UNECA (United Nations Economic Commission for Africa), 2008).

According to the World Bank (2001), the size of the informal economy as a percentage of gross national income ranges from under 30 percent in South Africa to about 60 percent in Nigeria, Tanzania and Zimbabwe. The size and role of the informal sector in the economy increase during economic recessions and periods of economic adjustment and transition. In the case of Zimbabwe, the informal economy has overshadowed the formal economy due to a combination of economic and political crises and unfavourable weather conditions in the form of recurrent droughts which forced a number of companies to close down. 


\section{REVIEW OF RELATED LITERATURE ON STREET FOOD VENDING}

Street food vending is a prevailing and distinctive component of a broad informal sector. Street food trade is a growing urban phenomenon in Zimbabwe. It is commonly viewed in public spaces particularly in the cities and towns. (Tinker, 1997) defines street food as any minimally processed food sold on the street for immediate consumption. Street food is defined as ready-toeat food or drink sold on a street or other public places, such as a market or fair by a hawker or vendor often from a portable stall (Artemis and Bhat, 2000). (Dardano, 2003) defines street food as food prepared on the streets and ready-to-eat, or prepared at home and consumed on the streets without further preparation. Street foods include snacks, main meals, or beverages. They often reflect traditional local cultures and exist in an endless variety (Winarno and Allain, 1991) but there are some street foods that have spread beyond their place of origin. Street foods are usually sold from pushcarts, kiosks and temporary stalls and cost less than a restaurant meal.

Street food businesses are usually owned and operated by individuals or families. Street food enterprises are generally small in size; require relatively simple skills, basic facilities and small amounts of capital. Marketing success of the street food vendors depends exclusively on location and word-of-mouth promotion (Winarno and Allain, 1991).

There is increasing recognition that street food vending plays an important socio-economic role in terms of employment potential, providing special income particularly for women and provision of food at affordable costs to mainly the lower income groups in the cities (Chukuezi, 2010). Street food vending employs on average 37.8 percent of the labor force, and contributes about 38 percent to total gross domestic product in Africa (Charmes, 1998). Women predominate in street food business representing 53 percent of the vendors in Senegal (Winarno and Allain, 1991) and 75 percent of the vendors in Burkina Faso (WHO (World Health Organisation), 2006).

According to FAO (Food and Agriculture Organisation) (2007), over 2.5 billion people eat street food every day. A longitudinal study of food consumption patterns in Bamako showed that street food accounts for 19-27 percent of food expenses and provides 134.417kcal per day per person (WHO, 2006). According to (Muzaffar et al., 2009) street foods provide a source of affordable nutrients to the majority of the people especially the low-income group in the developing countries. According to (Muzaffar et al., 2009) street foods provide a source of affordable nutrients to the majority of the people especially the low-income group in the developing countries.

Concerns of cleanliness and freshness often discourage some people from eating street food. With the increasing pace of globalisation and tourism, the safety of street food has become one of the major concerns of public health and a focus for governments and scientists to raise public awareness (FAO, 2007; Mukhola, 2007). An assessment of some street foods widely consumed in Ouagadogou, Burkina Faso showed that vendors did not respect hygienic practices (WHO, 2006). In Accra, Ghana, a study to evaluate the role of street food vendors in the transmission of diarrhoeal pathogens showed that in 35 percent of the vending sites food was exposed to flies while 17.1 percent of the vendors handled food at ground level (WHO, 2006). In the United Kingdom, the Food Standards Agency provides comprehensive rule of food safety for the vendors, traders and retailers of the street food sector. In Mumbai, India, the Food safety Act, 2011 
requires hawkers, food vendors including vegetable and fruit vendors to follow basic hygiene rules such as wearing an apron and gloves and using clean utensils and potable water. Other effective ways of enhancing the safety of street foods are through mystery shopping programmes, through training and rewarding programmes to vendors, through regulatory governing and membership management programmes, or through technical testing programs.

Opponents of street food vending component of the informal sector argue that the informal sector is incapable of playing any developmental role and that the people in this sector are destined to remain marginal to the rest of the economy (Sethuraman, 1981; Manning, 1993). Under this trend of thought the businesses in the informal sector are classified as survivalist enterprises that will not drive economic growth in developing countries and in fact will disappear over time as the formation of official firms increase to stimulate growth in the formal sector (Sethuraman, 1981; Ruel et al., 1999). They note that these businesses have owners with limited skill training, little capital investment which oftentimes translates into limited opportunities for growth into a viable business. The views of opponents of informal sector entrepreneurship are based on misguided assumptions and not empirical data (Tinker, 1997). The advocates argue that the scarcity of statistics not only down plays the significance of women's entrepreneurship in the informal sector but poses a problem in quantifying with any precision the economic contribution of these activities to the economy of developing countries, particularly in Africa (Tinker, 1997; Sardier, 2003; Verick, 2006). The omission of informal activities from economic accounting statistics may significantly underestimate gross domestic product and overestimate the share of the population living below the national poverty line. Disproving much of the early development literature, recent statistics indicate that "the informal sector has not only persisted but actually grown in many developing countries, particularly in Africa where it dominates the economy both in terms of output and employment" (Verick, 2006).

\subsection{Statement of the Problem}

As urban population grows due to escalating rural-urban migration, the government and municipal authorities will face unique challenges in their efforts to ensure the economic and social well-being of people residing in the urban areas. In particular, they will have to take into account changing ways of enhancing household livelihoods and food security through informal activities. The major challenge is how to incorporate unregistered informal business enterprises into urban planning in a manner that would ensure their sustainability and safeguard both people and the environment. Lack of research on street food industry has contributed to an underestimation of the contribution of this sector to economic growth and sustainable development. This study made a contribution to filling this lacuna.

\subsection{Study Objectives}

The study's primary aim was to investigate the nature and operations of street food vendors, identify the nature of the problems and impediments faced by the street food vendors including socio-economic features influencing street food vending spatial distribution and its impact on the 
local environment and urban life in Harare, Zimbabwe. The specific objectives of the study were to:

- $\quad$ analyse emerging street food vending patterns in the high density suburbs,

- $\quad$ examine the socio-economic role of street food vending,

- $\quad$ identify the nature of problems affecting street food vendors,

- determine the overall impact of street food vending on the City's environment and sustainable urban life,

- $\quad$ make suggestions for policy recommendations to enable planning and development of safe and sustainable strategies of street food vending.

\section{Research Questions}

- What are the emerging street food vending patterns in the high density suburbs of Harare?

- What are the socio-economic functions of street food vending in Harare?

- What is the nature of problems affecting street food vendors?

- What is the overall impact of street food vending on the City's environment and sustainable urban life,

- What policy recommendations to enable planning and development of safe and sustainable strategies of street food vending.

\subsection{Description of the Study Area}

Harare is the largest city and capital of Zimbabwe. It has an estimated population of 2.8 million. Harare was selected for the pilot study because the city experienced the highest growth of street food vending especially in the high density suburbs. Harare has 36 suburbs where 15 are high density, 8 are medium density and 12 are low density suburbs. There is one informal settlement in Harare called Hopley. Dominant human activities in Harare's high density suburbs include illegal stream bank and unutilised space agriculture and street vending. Figure 1 shows a map of Greater Harare and the six study sites of Budiriro, Highfield, Glen Norah, Glen View, Mufakose and Warren Park. All the six high density suburbs are found on the west of the central business district.

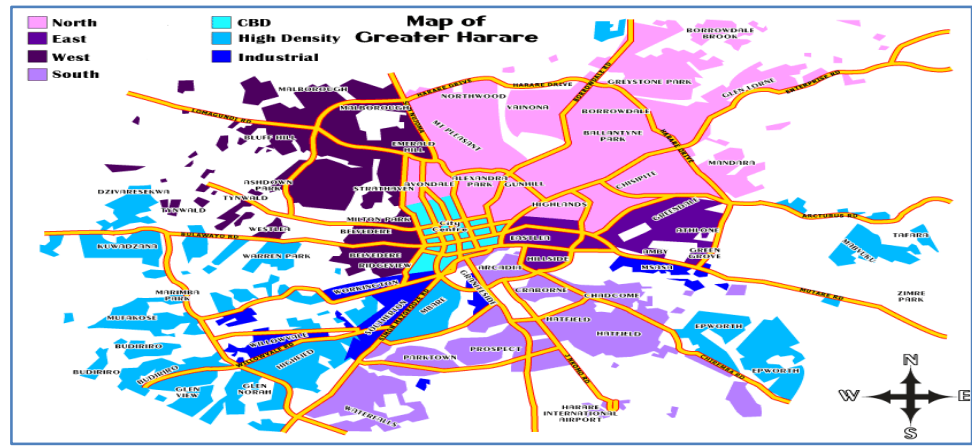

Figure-1. Map of Greater Harare Showing the Study Sites. 


\subsection{Study Methodology}

The study used both quantitative and qualitative data collection techniques. These included field notes, in-depth personal interviews, direct participant observations and documentary reviews so as to triangulate the evidence. A semi-structured questionnaire was used as the basic tool to collect socio-economic and technical data pertaining to street food vendors. This enabled the researcher to ask standardised questions and to collect uniform data from the selected vendors. The questionnaire was administered by the researcher at the respondents' vending sites where the researcher used that opportunity to start group discussions with vendors present to hear their views concerning research issues. The data extracted from the questionnaire survey included age, sex, marital status, level of education, initial income invested, place of food preparation, whether licensed to operate, problems encountered while doing business, number of employees and the major customers. Descriptive statistics such as means and frequencies were used to present the findings.Six high density suburbs of Budiriro, Highfield, Glen Norah, Glen View, Mufakose and Warren Park were selected as the study area on the basis that these are representative of the typical high density informal sector business activities in Harare. Sixty street food vendors were randomly selected in the six high density suburbs. This was done to avoid bias in the selection of the respondents. Within the suburbs, the researchers randomly selected and interviewed ten street food vendors after they had given their consent and had been assured total confidentiality. Focus group discussions were held with some vendors in order to obtain in-depth information. Indepth interviews were held with officials from the City's Departments of Health, Housing and Community Services and Surveying as well as some of the major customers of street foods in order to enrich the study.

\section{RESULTS AND DISCUSSION}

Street food vendors can be observed in most public places including industrial and construction sites, hospitals, schools, sporting stadia, bus termini, shopping and commercial centres, in front of offices and along virtually every street of Harare's High Density Suburbs. Street vending is also taking root even in the low density suburbs, an indication of a deepening economic crisis. Figure 2 shows the main categories of street foods in Harare. More specifically, the scope of main meals is quite broad including sadza (maize meal) and rice served with beef stew, roasted beef or pork, mazondo (cow heels), musoro (cow head), beef knuckles, roasted chicken, fish and pork trotters. The snacks included steamed or roasted mealies (corn) fried potato chips and beef and pork sausages while beverages included both alcoholic and soft drinks. Some vendors were selling illicit imported spirits.
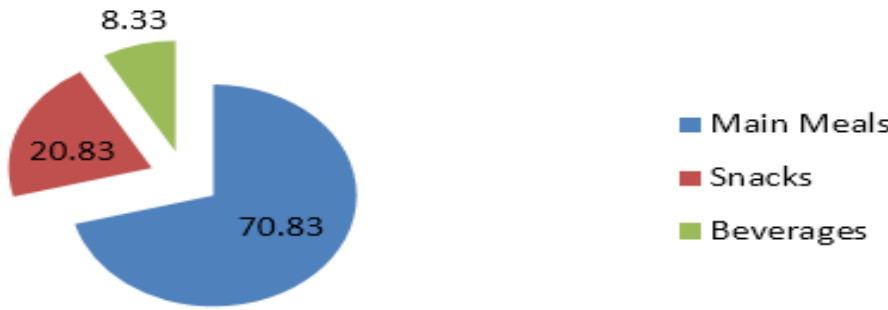

Figure-2. Main Categories of Street Foods in Harare High Density Suburbs. 
Figure 3 shows that women predominate in street food vending representing 85 percent of the vendors. This is due to a number of socio-economic factors such as failure to secure formal employment due to lower education and lack of professional skills. Also household work such as child care may force some women into street food business. This is because street food business would allow a woman to do other household chores besides vending. The third factor is that street food business requires relatively small capital base and hence easier to penetrate by housewives. In-depth interviews revealed that a majority of the females engaged in street food vending in order to supplement their husbands' lower wages. However, as the economic crisis deepens, an increasing number of men are engaged in street vending as their sole source of livelihoods. Men usually

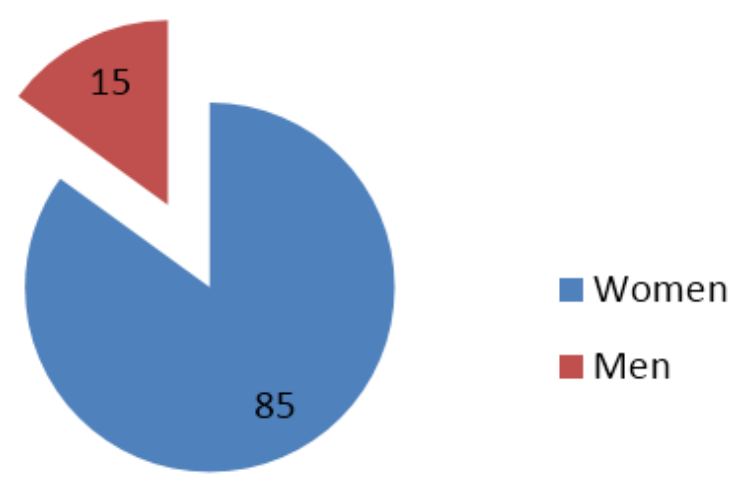

Figure-3. Street Food Vending Participation by Sex.

Table 1 shows the socio-economic and demographic characteristics of street food vendors in the six high density suburbs of Harare, Zimbabwe. A majority of the food vendors (46.7 percent) are in the 21-30 years age group. This is the economically active age group and their participation in street food industry reflects the high unemployment levels in the country. The informal sector and in particular street food vending, because of relatively low capital requirements has become the only source of income for the unemployed. Peak prevalence in education is Ordinary Level with 55 percent of all those surveyed. Those who failed to reach Ordinary Level are female and cited various reasons which included economic (financial) (73 percent), social (for example, early pregnancies) (16 percent) and inability or unwillingness to continue their education (11 percent).

Table 1 also shows that 75 percent of street food vendors lived in rented houses. About 90 percent of the vendors relied solely on street food vending. This shows that food vending, though illegal has helped to reduce unemployment and enhance livelihoods of most urban households. This confirms that Harare residents resort to street food vending as a coping and survival strategy in the face of high unemployment and lower wages in the formal sector.

Table 2 shows that the majority (50 percent) of the initial investment made in the street food vending business was over $\$ 40$ and came from own savings (90 percent). Investments of over $\$ 40$ were made mainly by women. These womenreceived the money to start business from their husbands. This shows that street food vending is undertaken as a copingstrategy to supplement husbands' low wages. This was corroborated by the uses of the income from food vendingbusiness. 
Table-1. Characteristics of street food vendors in Harare.

\begin{tabular}{l|l}
\hline Parameter & Percentage (Frequency, n=60) \\
\hline Age (years) & \\
\hline Below 20 & 0 \\
$21-30$ & 46.7 \\
$31-40$ & 31.7 \\
$41-50$ & 13.3 \\
$51-60$ & 5.3 \\
Over 60 & 3.0 \\
\hline Sex & \\
\hline Male & 15 \\
Female & 85 \\
\hline Marital Status & \\
\hline Single & 25 \\
Married & 55 \\
Divorced & 10 \\
Widowed & 10 \\
\hline Educational Qualification & \\
\hline Zimbabwe Junior Certificate & 25 \\
Ordinary Level & 55 \\
Advanced Level & 11.7 \\
Diploma & 5 \\
Degree & 0 \\
Other & 3.3 \\
\hline Type of Housing & 15 \\
\hline Owned & 75 \\
Rented & 10 \\
Other & 90 \\
\hline Alternative source (s) of income & \\
\hline Yes & \\
No & \\
\hline & \\
\hline
\end{tabular}

Most street food vendors used their income to meet household requirements such as paying rent, rates, water andschool fees and buying groceries and clothing. Informal rotating savings and credit schemes are common among street food vendors and offer sources of working capital.For example in Glen View 8, everyday each vendor contributes $\$ 10$ to the rotating savings schemewhich benefits one ofthe vendors on that particular day. The additional income is used to boost the working capital of the recipient vendor. The majority (95 percent) of street food vendors claimed that they prepared basic books of accounts for their business.About 60 percent of the food vendors indicated that they required training in business management, catering and foodhandling. The majority of them said that they were willing to pay for the training.All the street food vending sites are open spaces at busy shopping centres, bus termini and industrial sites. All of thevendors surveyed were stationary and used temporary wooden or polythene stalls. The vendors' stalls have low-costseating facilities which are sometimes rudimentary. The majority of the street food vendors, (98.3 percent) used eitherfirewood or waste paper to prepare food. 
Table-2.Initial income, books of accounts, registration status and number of employees.

\begin{tabular}{|c|c|}
\hline Parameter & Percentage (Frequency, $n=60$ ) \\
\hline \multicolumn{2}{|l|}{ Initial Income, US \$ } \\
\hline Below 20 & 0 \\
\hline $21-30$ & 20 \\
\hline $31-40$ & 30 \\
\hline Over 40 & 50 \\
\hline \multicolumn{2}{|l|}{ Source of Income } \\
\hline Own Savings & 90 \\
\hline Loan from bank & $\mathrm{O}$ \\
\hline Loan from relative $(\mathrm{s})$ & $\mathrm{O}$ \\
\hline Donation & 10 \\
\hline \multicolumn{2}{|c|}{ Period operating business (years) } \\
\hline Below 1 & 60 \\
\hline $2-3$ & 5 \\
\hline Over 3 & 35 \\
\hline \multicolumn{2}{|c|}{ Availability of books of accounts for the business } \\
\hline Yes & 95 \\
\hline No & 5 \\
\hline \multicolumn{2}{|c|}{ Registration Status of the Business } \\
\hline Registered & 1.7 \\
\hline Not registered & 98.3 \\
\hline \multicolumn{2}{|l|}{ Number of employees } \\
\hline Nil & 55 \\
\hline One & 15 \\
\hline Two & 15 \\
\hline More than two & 15 \\
\hline \multicolumn{2}{|c|}{ Business Operating times } \\
\hline $6 \mathrm{am}-7 \mathrm{pm}$ & 41.7 \\
\hline 6am-10pm & 58.3 \\
\hline
\end{tabular}

The majority (55 percent) of the street food vendors were small scale entrepreneurs of owner-operated businesses who worked alone or with the help of unpaid family member(s). Family labour including children was crucial inside and outside the home and increased with economic downturn.

From the survey, children helped their parents or guardians in washing dishes and preparing food. From the survey, 45 percent employed between one and eight workers. This showed that although street food vending is not recognised, the industry has helped to reduce unemployment in the city. Table 3 shows the major customers of street food in Harare's high density suburbs. Bottle store and bar patrons (30.2 percent)are the major consumers of street foods in Harare. The main reasons given by those who drink beer are that beer goes wellwith sadza (maize meal) and beef especially musoro (cow head) or mazondo (cow heels) and that street food has flavorvariety which lacks in some homes. Local residents make up 20.9 percent of the customers of street food in the study area.

The growing mega trends for street food could be attributed to preference for locally produced organic food and widening offlavour concepts in fast food. In addition some Zimbabweans now work for longerhours and street food vendors provideconvenient and delicious meals. 
Informal traders involved in petty trading (for example flea market traders) and informal artisans including metal workers,carpenters and motor mechanics and panel beaters and workers from established shops and public utility offices such as theZimbabwe Electricity Supply Authority (ZESA) constituted another significant group of consumers of street foods (32.6percent). These preferred street foods because they are easily accessible, wide variety, affordable and flexible paying optionsfor regular customers. A survey of established shops where street food vending takes place showed that some of the shopshave actually reduced or have completely stopped selling fast food and snacks. The most important thing about streetshopping is that one is dealing with a human person, prices are usually negotiated and in some cases informal credits are granted to customers. On the other hand, the treatment in shopping malls is mechanical and the transaction lacks humanitywhich is always present in street commerce.

Table-3.Major customers of street foods in the high density suburbs of Harare

\begin{tabular}{l|l}
\hline Parameter & Percentage (Frequency, n=60) \\
\hline Major customers & \\
\hline Local residents & 20.9 \\
Informal sector employees e.g. flea market & 18.6 \\
traders & \\
Workers from shops, Harare district offices, & 14.0 \\
other utilities e.g.ZESA, TelOne etc & 16.3 \\
Commuter omnibus crews & 30.2 \\
Bottle store and bar patrons & \\
\hline
\end{tabular}

\subsection{Formality and Regulation of Street Food Vending}

Table 3 shows that 98.3 percent of the businesses were not registered by the Harare City Council. This is because the City by-laws do not allow vending of cooked food. The Harare City Council gives licenses to vegetable vendors only and the vendingshould take place at designated places (which are very few in number). Because street food vending is an unrecognized industry has often justified harassment of the vendors by the local authorities. The majority of unlicensed vendors complained about raids and confiscations of their food and cooking pots by both the Zimbabwe Republic Police and municipal police. The fine charged is US $\$ 20$ which might be 25-30 percent of a vendor's monthly income. Police raids haveat times led to riotous situations and loss of property. For example on 10 January 2012, street vendors shattered the windowsof a police post in First Street, Harare after the police confiscated their wares. The major problem is that the city's master plan (designed during the colonial period) does not allocate space to vendors as town planners blindly replicate the western concept of marketing which ignores the Zimbabwean traditions. The modern development approach is oriented towards shopping malls which are not built on the concept of a public that cannot afford to live expensive lifestyles.

\subsection{Issues of Hygiene and Congestion}

The street food industry is spread over different locations and is not systematically coordinated which makes the Harare CityCouncil to regard such clusters of street food vendors as impediments to urban planning and hazards to public health. About99 percent of the street food 
vending sites in the study area lacked potable water and proper facilities for cleaning dishes andwaste disposal.

Water for washing dishes was often recycled. About 82 percent of the public toilets were not in working orderforcing vendors to use toilets in shops and bars and open spaces at night. In addition, the vendors did not have protective clothing such as chef's hats, aprons and gloves posing a health hazard to workers and customers. In the entire study area, only three percent of the vendors had aprons but did not have gloves. Inconvenient and unhygienic eating places were also some of the infrastructural problems observed during the survey. Congestion and lack of water and sanitation created hazardous environment for both the vendors and customers. This is usually experienced where vendors sell their wares on established shops' verandahs and along road sides where they obstruct free flow of traffic and movement of pedestrians.

The other problems faced by street food vendors when doing their business included competition from new entrants, erraticsupply of raw materials, lack of business management skills (especially vending skills), lack of proper food handling techniques and hostile customers (especially men), some of whom seldom refuse to pay.For those workers employed in the street food vending sector, they do not benefit from minimum wage and social security provisions and have to provide for their own health and retirement needs. In addition, many of them complained that they are subjected to harassment and exploitation from their employers, police and municipal authorities.

\section{CONCLUSION AND RECOMMENDATIONS}

The study showed that street food vending is a vital community development tool as it plays very important socio-economic role in today's Harare in particular and Zimbabwe in general. Street food vending, far from being a hindrance to progress and sustainable development, is in fact the basis of an alternative street economy which is people friendly and with the necessary institutional and infrastructural support can be both environmentally-sensitive and energy conscious. Street foods are an important but an unexplored facet of Zimbabwe's food and nutrition. Although street food vending is illegal, it significantly helped to reduce unemployment, increased incomes of vendors and provided urban dwellers with inexpensive and varied and nutritious indigenous meals. This significant role is threatened by claims that such vending constitutes a major source of food-borne diseases (through poor hygiene) and cause congestion in the city. This has often justified harassment of street vendors by the local authorities. The government should recognise street food industry through legislation and introduction of a code of practice for street food vendors.

Formalisation through legislation of vending on the streets will make it easier for the vendors to thrive while working within the existing regulatory framework. The regulations would need to be designed equitably and vendor license fees charged should be sustainable so that vendors are able to stay within the regulatory framework. In addition, the regulations should integrate the interests and ideas of street vendors and relevant policy makers in order to develop a sustainable model of street food vending that would secure and strengthen the livelihoods of the vendors. 
The local authorities should construct decent shelters which can be rented by food vendors. Alternatively, the city council can construct a prototype model for food vending stall or kiosk which will be made available for sale possibly through microfinance. In addition, the city council should provide essential public utilities such as potable water, garbage collection, electricity and public toilets. This will entail creating space for vending for old suburbs and including vending space for new suburbs.

In Hong Kong, China, Singapore and Malaysia, local authorities construct hawker centres which are open-air complexes that house many stalls selling a variety of inexpensive food. These complexes were built partly to address the problem of unhygienic food preparation by unlicensed street vendors. Street food vending has tremendous benefits to customers. The advantage of open air vending sites is that they are often popular with tourists who want to taste indigenous foodswhich are not served in hotels, restaurants and fast foods outlets. In Latin America, street food purchases account for up to 30 percent of urban household spending whilst in Bangkok, twenty thousand street food vendors provide city residents with an estimated 40 percent of their overall energy intake (FAO, 2007).

What is needed to advance the position of street food vendors is to strengthen their capacities and skills through training in food handling, credit, information and infrastructure so as to enhance their productivity. As a first step towards recognition, street food vendors should constitute themselves into well organised associations which would enable them to develop codes for their businesses or constitute a forum for interaction with the Department of Health of the City of Harare and Ministry of Health and Child Welfare. There is need for more research to describe the nature of street vending and quantify the consumption of street foods in Zimbabwe and their economic benefits as well as ways to improve the standards of street food.

In light of the findings of this research, the following specific recommendations can be drawn with a view of improving the competitiveness and sustainability of Harare's food vending sector;

- Non-governmental organisations and vendors should start regular consultations to coordinate advocacy programmes with a view to recognition and formalisation of street vending.

- Non-governmental organisations and academics should conduct action-oriented research to compile data to identify and profile the nature of vendors (mobile, semi-mobile, static and footpath vendors).

- $\quad$ Public awareness for vendors to understand agencies that regulate vending in Harare and register for certificate of authority to operate as street entrepreneurs.

- The City of Harare should identify public spaces and give them to vendors and the town planning department should coordinate with Zimbabwe National Water Authority (ZINWA), Zimbabwe National Road Administration (ZINARA) and Zimbabwe Electricity Supply Authority (ZESA) to include vending spaces for new suburbs.

- Non-governmental organisations and Harare City Council should design on the job training seminars for street vendors on issues of capacity building, marketing skills, business development and hygiene in the production of safe food. 


\section{REFERENCES}

Artemis, P.S. and R.V. Bhat, 2000. Street foods. Basel: Karger Publishers.

Beneria, L. and M.S. Floro, 2006. Labor market informalisation, gender and social protection: Reflections on poor urban households in Bolivia, Ecuador and Thailand, in Razavi S.and Hassim S., Eds. Gender and social policy in a global context: Uncovering the gendered structure of the social. New York: Palgrave Macmillan.

Charmes, J., 1998. Women working in the informal sector in Africa: New methods and new data. New York: United Nations Statistics Division.

Chukuezi, C.O., 2010. Entrepreneurs of the streets: Socio-economic features of street food vending in Owerri, Nigeria. European Journal of Social Sciences, 14(2): 183-188.

Dardano, C., 2003. Carribbean regional working group on street food vendors, Report of FAO, PAHO and BNSI. Available from: http://ftp.fao.org/es/esn/food/carribean_report.pdf, [Accessed 25 August 2011].

FAO (Food and Agriculture Organisation), 2007. School kids and street food, spotlight magazine. Agriculture and Consumer Protection Department, United Nations. Available from http://www.fao.org/AG/magazine/0702sp1.htm [Accessed 25 August 2011].

ILO (International Labour Organisation), 2002. Men and women in the informal economy. Available from http://www.ilo.org/public/english/employment/gems/download/women.pdf

[Accessed 24 October 2011].

Manning, C., 1993. International experiences of informal sector activity and the lessons for South $\begin{array}{llll}\text { Africa. } & \text { Transformation, } & \text { (22). frailable }\end{array}$ http://www.transformation.ukzn.ac.za/archive/tran022/tran022006.pdf [Accessed 24 October 2011].

Mukhola, M.S., 2007. Guidelines for an environmental education training programme for street food vendors in Polokwane City. Available from: http://etd.rau.ac.za/theses/submitted/etd-03132007-140510/restricted/last.pdf, Unpublished Thesis, [Accessed 25 August 2011].

Muzaffar, A.T., I. Huq and B.A. Mallik, 2009. Entrepreneurs of the streets: An analytical work on the street food vendors of Dhaka City. International Journal of Business and Management, 4(2): 80-88.

Ruel, M., C. Levin, S. Morris, D. Maxwell, M. Armar-Klemusu and C. Ahiadeke, 1999. Working women in an urban setting traders, vendors and food security in Accra. World Development Report, 27/11: 1977-1991.

Sardier, M., 2003. Women's socio-economic roles in the urban Sahel: A preliminary study of Bamako and Niamey. Journal of Political Ecology, 10(1): 47-56.

Sethuraman, S.V., 1981. The urban informal sector in developing countries: Employment, poverty and environment. Geneva: International Labour Office.

Tinker, I., 1997. Street foods: Urban food and employment in developing countries. New York: Oxford University Press. 
UNECA (United Nations Economic Commission for Africa), 2008. Achieving gender equality and women's empowerment in Africa, progress Report, The African Development Forum (ADF VI) 19-21 November 2008, Addis Ababa. Available from: http://www.uneca.org/adfvi/documents/ADFVI_Progress_Report_ENG.pdf

[Accessed on 16 November 2011].

Verick, S., 2006. The impact of globalisation on the informal sector in Africa, Addis Ababa: UNECA. Availabe from: http://www.iza.org/conference_files/worldb2006/verick_s872.pdf [Accessed on 22 March 2012].

World Health Organisation, 2006. Street food vending in the region. Food Safety Challenges. AFRO Food Safety Newsletter, (2). [Accessed July 2006].

Winarno, F.G. and A. Allain, 1991. Street foods in developing countries: Lessons from Asia. Rome: Food and agriculture organisation. Available from: http://www.fao.org/docrep/U3550T/U3550Too.htm, [Accessed 24 October 2011].

World Bank, 2001. World development report 2000/2001: Attacking poverty. Washington D.C. World Bank. 